\title{
Spanish History in the Fairy Country: Dealing with Social Trauma in Pan's Labyrinth
}

\section{Álvaro Fernández \\ QueEns COLLEGE, NeW YORK·alvaro.fernandez @qc.cuny.edu}

Licenciado en Letras por la Universidad de Buenos Aires y doctor por Stony Brook University. Ha trabajado como docente e investigador en la Universidad de Buenos Aires y la Universidad de La Plata en Argentina. Actualmente es profesor de literatura y cine en Queens College de la City University of New York. Estudia las significaciones políticas de las formas de la memoria histórica, especialmente en obras donde esta aparece menos destacada.

\section{RECIBIDO: 10 DE OCTUBRE DE 2013}

ACEPTADO: 20 DE NOVIEMBRE DE 2013

Resumen: La celebrada El laberinto del fauno (Del Toro, 2006) pone en escena un cuento de hadas situado en los convulsos tiempos de la primera posguerra civil española. La crítica ha señalado las dificultades para evaluar la conflictiva relación entre historia y fantasía en el ambiguo final feliz de la película, y ha tratado de relacionar la moraleja final con el trauma de la Guerra Civil.

En este trabajo, preferimos leer el film a la luz de otro trauma social, el que marca el momento de su producción. Si tenemos en cuenta que la Transición de una dictadura fascista a una monarquía parlamentaria no ha sido abierta ni pacíficamente debatida en las décadas siguientes y que cierto silencio sobre este tema persiste todavía hoy; es posible entender la película como una forma de abordar algunos asuntos pendientes de la cultura española contemporánea.

Palabras Clave: Laberinto del Fauno, Del Toro, Trauma Social, Memoria Histórica, Transición Española, Cultura Española.
Abstract: The successful film El laberinto del fauno (Del Toro, 2006) presents a fairy tale set in the convulsive times of the Spanish Civil War's aftermath. The scholarship on this film already established the difficulties inherent in evaluating the conflictive relation between history and fantasy in the movie's ambiguous happy ending and has tried to relate the film's moral with the social trauma of the Civil War. In this essay, we chose to read the film in the light of another social trauma, that which marked the moment of its production. Considering that the Transition from a fascist dictatorship to a parliamentary monarchy has not been openly and peacefully discussed in the subsequent decades, and that a tense silence in regards to this topic continues to this very day, it is possible to understand the movie as an attempt to address some unfinished business in contemporary Spanish culture.

Key Words: Pan's Labyrinth, Del Toro, Social Trauma, Historical Memory, Spanish Transition, Spanish Culture.

DOI: 10.7203/KAM.2.3154 
In recent years, a new public discussion has arisen in Spain about its historical past. Over the course of the twentieth century authoritative narratives of national history have been hotly contested, both during and after the Francoist dictatorship. The pendulum has swung from strict state control during the Franco era to drastic overexposure after his death, from the indifference of la Movida in the 1980s to the imposition of therapeutic distance in conjunction with the 1992 celebrations that confirmed Spain's place among the modern nations of the world. As one of the spoils of victory, Franco was able to control and manipulate representations of the past to create a paradigm of National Catholic Spanish history that would be taught in schools and universities over the next forty years. In the 1970s, national history surged to the forefront as a prestigious artistic topos. Books and films addressing historical events attracted favourable attention, such as being accepted by a major publishing house or notable film producer, and winning literary or cinematic awards. However, the darker aspects were condemned to silence with the stated intention of avoiding another military confrontation between 'the two Spains' - a pretext that was actively used during the regime's final decades and the first years of the transition to avoid addressing the matter. In the wake of the Pinochet Affaire, twentieth-century Spanish history acquired new significance and visibility in the media: the civil war and its aftermath, the harsh dictatorship, the repression, all become fodder for media representation. Over the past decade, discussion of modern history has become active and visible again, exposing among many other things that it brings to light - that not all the wounds have been effectively closed in Spain and that, certainly, the old discussions between Republicans and Fascists continue into the present day. Of course, there can be no single method or aesthetic for addressing a past that has persisted as an ambiguous object, an uneasy territory desired and feared at the same time, rewritten from multiple and conflicting points of view. In this context, it is productive to consider El laberinto del fauno as a box office smash that employs a unique artistic vision to address this highly controversial past.

In Guillermo del Toro's 2006 film El laberinto del fauno history and fantasy are intertwined; it presents elements that belong to the historical past on the same level as a fairy tale that includes princesses and kings. Even though the film starts and ends framed within contemporary Spanish history, the whole narrative is contaminated with the logic of fairy tales that interacts with the historical level, imposing upon it its own laws of verisimilitude. The opening shot - white text on a black background - sets us temporally and spatially in a conflict zone - 'España, 1944' - meanwhile we listen to agonic breathing and the humming of the lullaby that is the movie's main theme. Another text explains more on the conflict: "La guerra civil ha terminado. Escondidos en las montañas, grupos armados siguen combatiendo al nuevo régimen fascista, que lucha por sofocarlos". Fading in from 
the black background, the camera tracks right to left, following moving red drops that we will soon understand as drops of blood falling in a hole. To do so, it is necessary to reconstruct the sequence: the camera is canted ninety degrees to the right. When it reaches a girl's face we learn the film is being screened in reverse motion: the blood drops go back into her nose, the camera turns to get a direct close up of the girl's face (meanwhile, an affected voice starts narrating the princess's story that will establish the fairy tale logic in the movie) and it tracks into the girl's left eye that will send us inside the underground kingdom. Just as the first images set the action in a specific historical context, now the camera goes back in time to explain the horrible crime from the magical point of view of a girl who believes in fairy tales.

From then on, the narration will be contaminated by this position. Even though the story of the child princess could be separated from the fight between the Francoist army and the republican partisans hidden in the woods, the magical logic of the fairy tale goes beyond the limits of the little girl's experience: the whole movie is ruled by the dichotomous opposition between good and evil, typical of the genre. Like fairy tales, the movie draws good or bad characters or, better yet, very good or very bad ones.

The difference between heroes and villains is more than clear and it is defined by political positions: Captain Vidal is a sadistic and cruel Francoist officer and the heroes are the partisans, bravely facing a powerful, tyrannical and tireless enemy. The movie divides the two sides between those heroes that fight, resist torture and risk their lives on the one hand, and the fascist regime that imposes strict laws upon the weak village population by controlling people's movements and rationing food and medicines, on the other.

The fairy tale has a happy ending, as it should: the fascist villain is defeated and even though he kills the innocent little girl, she returns to her kingdom and metamorphoses into a princess and reunites with her parents - both already dead in the violent historical world of the civil war's aftermath - that now reign as the monarchs in the fairy country. This description of the movie plot opens a series of questions: why is this story told in such a way, what sense does retelling the past through fairy tale codes have and, from that, how is this movie related to the politics of memory? Before even trying to address these matters, it is necessary to answer a previous and more basic question that would probably give a hint about how to solve all the previous ones: What story is Pan's Labyrinth, in fact, telling?

It could be thought, upon a quick reading, that the film narrates a comforting story while dealing with tragic times of fear, pain and defeat. Even though the villain kills the young girl, her resurrection in the fairy kingdom could be seen as a triumph that complements the partisans' pyrrhic victory: as many spectators know, only a few short years later they will have to go into exile and leave Spain in Franco's hands. The dictator will take thirty long years to die, but this is history: in the movie, the heroes win, the villains die and are condemned to be forgotten. 
Apparently the film has an unquestionably happy ending only for those viewers who do not know the tragic history of the progressive forces in Spain. Spectators around the world unfamiliar with Spanish history could easily relate the 1944 story narrated in the film with the imminent defeat of the other fascists in Europe and conclude that the maquis would have a beautiful, peaceful, long life educating the little baby in the democratic culture of a post-war Europe. The comforting ending, then, works only for those that do not know about or choose not to contextualize the film within its historical context.

Scholarship concerning the suggestive combination of fairy tales and history points out the need to extract a transcendental meaning for the film separate from the historical tragic narrative of the doomed resistance to fascism, a narrative that must be relegated to better evaluate the film's message. Thus based on the genre structure and its conventions, Hanley suggests that a didactic reading of the movie is natural and desirable but the historical references put it at risk:

The fairy tale narrative structure invokes the expectation of a moral lesson and a summary conclusion, but the ambiguities in this particular tale and its location in a concrete historical moment create a suggestive interplay between the empowerment of the child protagonist as a message of transcendence and ideas of resistance and choice, violence and power in history. (Hanley, 2007: 40)

In this view, the genre suggests a moral that is undermined by the concrete historical settings that are also present in the film. To get at the moral lesson it is necessary to think of the plot in a more abstract way. History has to be displaced or betrayed to make the typical fairy tale narrative function properly, teaching a lesson, sending a transcendental message that ignores or surpasses historical facts. The structure of popular stories in the movie, however, is not opposed to but strongly intertwined with the historical setting and works to strengthen its qualities as an artistic artefact (Deveny, 2008: 11). The film itself is not making explicit a contradiction between fantasy and history, both worlds work perfectly together and the structural elements of the popular fairy tales organize a coherent story told from a girl's point of view. As Deveny notes, she smoothly passes from one world to the other (2008: 1). The uncomfortable feeling that history is being betrayed lies outside the movie, in a historically conscious reading that underscores a contradiction that is not even suggested in the film.

But the opposition remains, however, when historical facts are considered alongside the movie's moral conclusion. Gavela Ramos proposes that the film doesn't merely narrate history but uses the mix of genres as a resource to face the collective trauma of the Civil War and its aftermath. In her view, the beginning of the twenty-first century offers the necessary distance to talk about traumatic events through cultural tools such as films that allow the spectator to widen his or her "collective memory" or "collective knowing" by 
constructing vicarious stories to face trauma (2011: 194). Thus the ambiguous ending that contradicts historical facts manages to leave an explicit and clear testimony of the violence of the civil war aftermath more than realistically narrate a story set in those tragic times. As in Hanley, the construction of a transcendental and moral image allows or probably asks for - due to the effects of a social trauma - a blurring of the concrete, historical reference.

Deveny - based on the director's opinions - minimizes the historical anecdote narrated in the film and goes beyond it by relating the moral of the story with the present historical context, one closer to the spectator. After analyzing the transitions between worlds and confirming the film's inscription in fairy tales genres, he concludes that the latter works both to construct a symbolic meaning and a formal structure that enable the film to deliver "a lesson that the director wants us to have in this post 9-11 world: the importance of choice and disobedience" (2008: 11). Even though Deveny reads the film in its strict historical context - the one in which the narrative is produced, read and understood -, he solves the contradiction posed by the happy ending and the historical facts represented in the movie by leaving aside one of the elements, the sad and tragic history of the Spanish resistance to Franco, the most conflictive to be dealt with in Spanish culture during and after the fascist dictatorship. The focus on universal moral lessons detaches the film from its more immediate historical meanings and makes it work as a standardized mainstream product that does not need to treat historical or socio-political references in a critical way. Seen this way, the film portrays so human and transcendental a message that it not only goes beyond history but also manages to remove it from a specific historical time. This reading also ignores the historically conscious response that typical Spanish spectators would experience in viewing a fascists-against-republicans story where the latter win and defeat fascists to restore - at least in the world of fantasy - the monarchy, a narrative that is not completely out of the realm of local politics. Even if the message were extremely valuable - the unlimited power of individuals when they fight for what they believe in -, it probably does not deserve to corrupt the historical facts - the collective fight of thousands of brave partisans who risked and lost their lives to defeat a fascist dictatorship that paradoxically ended up supported by the Western democracies.

In any case, the coexistence of genres is a problem for critics who consider the contradictory values handled in the ending when it is necessary to evaluate and decide the final meaning of the film - or, at least one meaning that could be defended without nuances. Even though Deveny's choice of reading the film in the political context of its production is effective at displacing the problem, Gavela Ramos' remarks on the historical trauma that affects Spanish spectators cannot be easily eluded. Moreover, the symbolism the movie openly develops could be interpreted in historical terms by reading it as a Spanish film that puts into play a story strongly linked with actual social traumas that affected Spain in 2006. A closer and historical reading that takes into account the local taboo narratives, which are 
not easily discussed, could bring to light other meanings implicit in the movie: a very clear symbolism in the context of contemporary Spanish history that is evident at the very surface of the film and that only needs a spectator willing to read it.

When we opt for a historical reading, we are not thinking of a comparison between the film's plot and the past represented in it, but of the most basic sociological reading of the movie, in relation with the socio-political context of the moment it was filmed. At the beginning of the twenty-first century - when Pan's Labyrinth was produced - Spain was discussing how to deal with its recent past, how to recover historical memory and give an account of an especially uncomfortable and controversial historical period of the country. The dominant tone of the movie - the fairy tale - could be thought as a willful attempt distance itself from serious positions on the topic. But this magical logic, however, is not far from some contemporaneous readings, interpretations and narratives that give a whitewashed account of Spain's past. Moreover, the most optimistic perspectives, which highlight the process of transition from the fascist dictatorship to the parliamentary monarchy, that consider as exemplary its handling of the uncomfortable past to create a better future, describe historical progress as a "miracle". Rooted in the national Catholic tradition that Spanish fascism built, this idea of a miracle puts aside - as fairy tales do rational explanations of history to provide a magical causality that moves its narratives.

Other positions less confident in the kindness of Providence hold that the Spanish transition, based both on covering up for the criminals and beneficiaries of the fascist dictatorship, may have contaminated the future. The transition was marked by blatant hypocrisy - readily apparent for those that really want to perceive it - concerning past crimes and their effects on the present. The institutional change - of regime and government - was contracted between the arriving politicians and the departing dictatorial regime with the support of King Juan Carlos. The King had been raised and educated within Franco's circle since childhood and ascended to the Spanish throne prematurely when the dictator asked his father to abdicate. The transition continued with the silence around the historical past that Francoism fought to establish with the alibi of avoiding a new violent confrontation, another "fratricide war". The active practice of this silence aimed to bring about, with the passage of time, a therapeutic amnesia concerning the civil war and its aftermath. There has never been complete agreement, however, about the positive and effective healing this strategy could bring about, especially taking into account the lack of justice for victims and criminals that it implies. Avoiding analysis, discussion and active research on such a close and painful period of time could also inadvertently bring about the traumatic emergence of those very episodes that this biased handling of the historical past intended to leave behind with the excuse of constructing a better future. 
Alberto Medina Domínguez calls into question the healing virtues of forgetting. In Exorcismos de la memoria, he describes the mechanism of modelling the historical past that begins during the Francoist dictatorship. After Franco's death begins "la obsesiva exterminación" of his memory (2001: 14), the need for forgetting the traumatic past symbolized by the emblematic image of the fascist leader. Thus the insistence on forgetting the trauma opens the process of melancholy that instead of burying the past, resuscitates it in the present. Paradoxically, the strategy of taking distance from the uncomfortable past has a disturbing side effect: the re-enacting of the macabre stories that come back as a symptom, with another face that makes them unrecognizable at first glance.

Teresa Vilarós in El mono del desencanto highlights the perils of blurring the origins of the contemporary Spanish administration: its intellectuals, politicians and high-ranking officials were educated in the Francoist cultural tradition, imposed upon the country for forty long years. Ignoring this fact only contributes to forgetting that many symptoms of the present are deeply rooted in this still active tradition. In her analysis, Vilarós states that the Spanish transition generated an alienated space in the present that blocks any attempt at constructing a future free of the traumatic ties with the forgotten past. She draws upon the image of a state of cultural, psychic, and emotional dependency between the Spaniards and Francoism that is similar to the abstinence syndrome of an addict: the sudden ending of the regime leaves them in limbo. Spanish culture after the transition would be oscillating "entre la modernidad y su pos, entre el duelo y la celebración, entre la producción y la destrucción, entre la esperanza y el desencanto" (Vilarós, 1998: 21).

Eduardo Subirats remarks that each image of Spanish culture at the end of the twentieth century - what is read, and what is valued as cultural - directly depends on how this culture is understood in relation with the transition and, from there, with the dictatorship. If the politics of forgetting become dominant, cultural productions will be read leaving aside politics and history, in the aseptic vacuum of an art inserted in an ideal society void of conflicts, discussions and confrontations (1995).

From these positions it is difficult to easily conceal that the cut with the Francoist regime -a harsh, National-Catholic dictatorship that during forty years applied strict politics of control, education and repression throughout Spanish society-, could have been done in such a clean and quick way without leaving any traces, with no consequences for the present. The regime's culture, its authoritarian, chauvinist and intolerant tradition - their rich panoply of values, judgments and attitudes patiently taught in classrooms, churches, jails and streets over those forty long years - could not magically disappear or be erased from the people's conscience and subconscious. Thus the transition "miracle" is more a process of disguising the near, uncomfortable past to turn it into a distant, closed and silenced time that cannot be accessed from the present. It is really surprising that such near and disturbing times could lose visibility and suddenly disappear from the public sphere 
and culture with the acquiescence of so many scholars, to be enveloped in a silence that eventually would lead to forgetting.

Analysis of the Spanish transition, on the part of those scholars that refuse to consider it as a magical and happy episode of contemporary Spanish history, plays a decisive role in understanding which parts of the uncomfortable past need to be forgotten, which need to be remembered and how to do it. Unlike the above scholars who stress the negative effects of the pathological amnesia fuelled by the concealed transmission of the political and economic power, authors like Ángel Loureiro and Santos Juliá demand the use of a therapeutic forgetting. And while they deny the mere existence of a pact of forgetting, they recommend the silencing of the conflictive past. Like most of the defenders of a hopeful amnesia, they strategically limit the Spanish trauma to the Civil War and its immediate aftermath, as Francoism did decades ago, in order to place equal responsibility for the tragedy on the defeated Republican forces. The next step is to diminish the importance of forty years of consistent repression and indoctrination. This version of the Spanish past reinforces the invisibility of the transition regarding politics of memory and confirms its miraculous character compared with other transitions around the world. The past becomes, thus, another country, a remote one that has lost any contact with the present, whose mention unnecessarily opens wounds that were closed many years ago.

Since it is within the framework of this ongoing debate about the past that the movie is being filmed, it is logical to read Pan's Labyrinth according to this larger context. We can think about which story the movie is telling us behind the struggle between the clearly defined forces of Good and Evil. At the very surface of the plot are the tasks that the girl has to fulfil to regain her place in the underground kingdom, the alternate reality that is proposed as ideal and fair. Also, at a very superficial level - no hermeneutics are necessary to read it - there is a second plot that is developed in the background: the succession. Captain Vidal is more interested in the survival of his first-born child than in his wife's: he has decided that his child will be a male, will take his mother's life if necessary, will bear the name of his father and grandfather - an officer who died fighting the Spanish-African colonial war - and will succeed him as the head of the family. This background plot, rooted in the historical world and that could remain unnoticed in a quick reading of the movie's story, is both crucial and silenced within the fairy tale: the engraving in the old stone in the portal shows the princess carrying the baby and guided by the faun to the underground kingdom. The challenges that the girl has to face include, at the very end, giving her life in exchange for her brother's. Pan's concern for the baby is not explained during the movie: when the girl asks him why her brother is so important, he avoids a direct answer and merely signals that the little heir is crucial for her return to the underworld. 
From her perspective, her escape is a reaction against Vidal, a way of rejecting his status as a stepfather and the military order her mother has resigned herself to live under.

When we read the movie in relation with the memory issues discussed in Spain at the time of its filming, we can clearly see how it symbolically puts into play a perfectly recognizable political plot hardly masked by the fairy tale codification. Moreover, this kind of narrative is not far from the idea of "miracle" that the defenders of a voluntary amnesia use to avoid a rational explanation of history and its consequent ethical or political discussions.

The movie's ending is the key to understanding what the film is narrating. After the young mother's death and the maquis' counter attack that weakens the military control over the small village, the girl runs away towards faun's labyrinth carrying her little brother, the desired heir that secretly moves the plot. The faun, handling a knife, wants to spill "innocent blood" to open the portal that conducts to the underworld and asks the girl to allow him to use her brother's. She cannot completely trust in the faun's intentions and prefers to give her life rather than risk that of her brother, the one who has taken her place as the family's primary heir. Captain Vidal finally finds the girl, takes the baby and shoots her. She falls at the edge of the pit, her blood drops to the deep, and we are back in the movie's first scene. Vidal leaves the labyrinth holding his heir and faces a triumphal and strong group of maquis that has tidily formed and is waiting patiently for him. With the formal manners of an officer that surrenders a position, he gives his heir to Mercedes, the uncultured maid that had disfigured his face. Thus the heir is passed to the side that maintains moral virtues and that fights against fascism to restore a democratic system. Completely defeated, Vidal has just one request related to memory: "Tell my son... tell him what time his father died," he asks them. The watch that belonged to the grandfather who died in Africa and that represents the military tradition that Vidal follows, is the concrete object that symbolizes the family heritage and memory. The maquis are categorical: "No, he will not even know your name." Precisely they - the morally upright, the fair, those that represent the good and the just against the francoist officer's authoritarian, cruel and bloody order - are the ones who choose oblivion as a recipe for a better future. The boy will grow up ignoring his father's name and in the movie there is no reflexion about the dangerous consequences of this decision at different levels: symbolic, psychological or even narrative, as fairy tales are very fond of blood heritage. 
After executing Vidal, the maquis enter the labyrinth and find the girl's dying body. From her exhausted hand pours a vivid and shiny red blood that contrasts with the predominant night blue of the scene composition. The camera then shows the pit's floor: the reflection of the moon in the water receives the red drops, an image that fulfils the prophecy - the blood of an innocent in the full moon. The camera continues showing the stone that summarizes the princess's duties in a frieze: the image represents a girl carrying a baby in her arms, guided by a faun. But when the camera is about to reach the boy's image, when it is about to recall the crucial role the heir has in the transit from one world to the other, it fades to a longer shot framing the whole stage. The rock with the frieze can be seen as part of the decoration and the baby has lost its importance (Figure 1). When he was about to appear in a close-up, the editing pushed him aside and lost him in a framing that dilutes his relevance. The same trick was used earlier in the abovementioned scene: the girl is interested in the role her brother plays in the challenges, but Pan changed the subject to divert her from thinking about the matter.

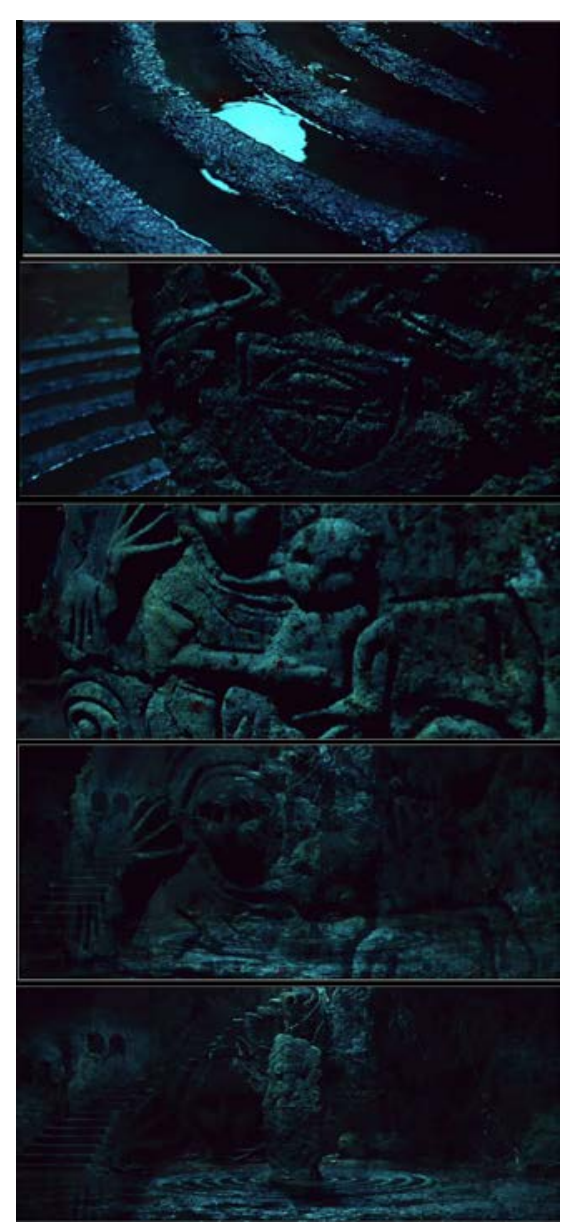

Figure 1: The fading hides the heir.

Back at the edge of the pit, Mercedes has the girl in her arms and hums her the song, whose lyrics she said had been forgotten, to lull her to sleep. Then, the girl is floodlit in warm yellow hues and a voice calls her: the passage is open. Bathed in the powerful light that erases the blue landscape of the historical world, the girl opens her eyes and tries to stand up. After a fading to gold, she is on her feet, looks at her hands completely clean of blood and her new clothes: the red is now the colour of an unbuttoned shiny cape that frames a yellow blouse. These are the colours of the Spanish flag - not the Spanish Republican flag but the current one, inherited from the Francoist dictatorship. She walks onto the impressive stage, a mix of palace, cathedral and parliament: at the back the king and the queen are seated on their tall thrones, with matching red cloaks framing yellow brilliant clothes, forming the flag that the rebel fascists imposed on Spain after the war. The girl recognizes her father: the king explains to her that she passed the last challenge and looks to his right, the camera tracks out to include the queen in the framing. She has 
something in her arms, but it can hardly be seen: it cuts to a long shot taken from behind the girl using a worm's eye perspective that includes the princess in the whole set dominated by Spanish ultranationalist colours (Figure 2). The queen has the little baby in her arms, but the editing makes him almost unnoticeable. The faun concludes that "your highness" did the right thing saving her brother's life. In a brief shot, her mother calls her to her side - now the baby is clearly in her arms and the audience in the balconies erupts in applause (Figure 3). The girl smiles, the image fades to gold and then we are back at the edge of the pit in the blue historical world. Mortally wounded, the little girl dies in Mercedes's arms: the maid is despondent and Pedro, the maqui leading the group holding the little baby, is visibly touched.

Even though as the internal logic of the narration has shown that before one can travel from one world to the other one has to die, the little baby is able to exist at both levels simultaneously. He serves as the secret driving force in this story of passages: every time the characters on camera were about to highlight his importance, the editing, the framing or the dialog steered the spectator's attention away from the subject. A careful reading of the movie shows that the heir that finally will inherit the throne is crucial in the story Pan's

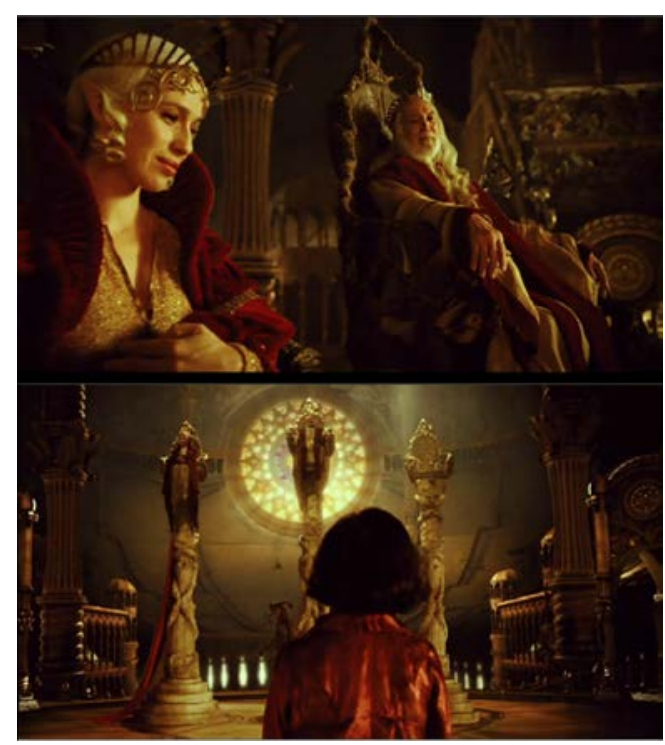

Figure 2: The heir is almost lost by the framing and the editing.

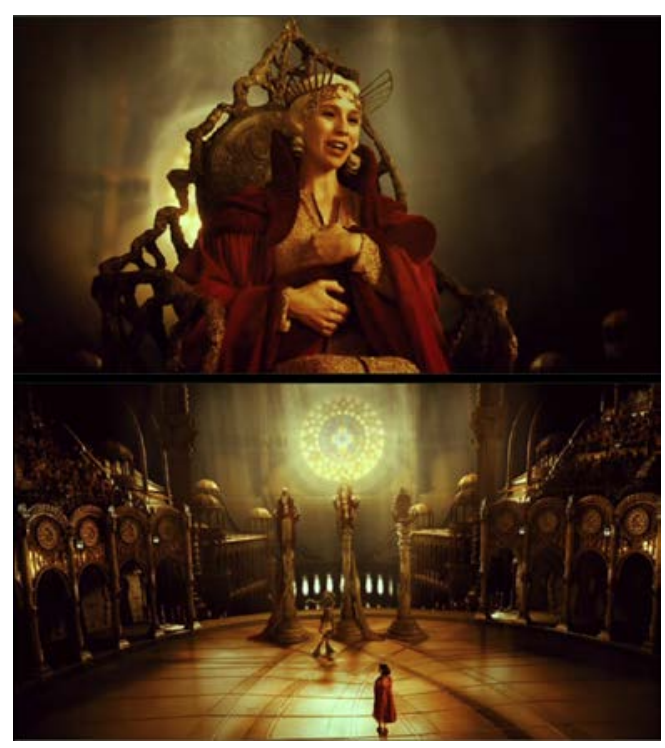

Figure 3: The queen is talking, the heir is shown for three seconds and the audience erupts in applause in the theatrical cathedral-parliamentpalace.

Labyrinth tells, especially if we understand the movie in terms of succession, inheritance and transition from a military order to another one: a democratic monarchy based on the silence over the connections of the throne's heir with the killers that ruled the country in a sad, blue past. 
The movie starts with a horrible crime - the little girl shot at the edge of a pit - that we must understand as a necessary sacrifice to reach a happy, monarchic restoration that is going to continue with an heir that was conceived and modelled as his successor by a cruel and bloodthirsty fascist that needs to be forgotten. The Spanish Republic was defeated by Franco, but there is a hopeful future that their heirs arranged when they decided to obscure the origins of the new king. They have chosen to apply a politics of forgetting in which it will be practical to leave behind the Francoist history of horrors and cruelty and step into a gold world accented with an elegant red that no longer evokes the innocent blood spilled in another, distant country: the past. In the underworld kingdom, the baby remains as a reminder of this story that took place in the blue world of history, as a prince who one day would come to the throne forgetting his origins, his connections with this historical, cruel world that has been happily isolated and buried in oblivion. The lullaby that functions as a leit-motif in the movie works also as a mediator to abandon the painful territory of history and to enter the fantastic magnificence of a monarchical order that is not interested in ethical details: the mother who has conceived a son with a bloodthirsty fascist smiles, accepted by her husband, the king, with the heir in her arms.

The ambiguous happy ending leaves a bitter taste and depicts an image of the Spain where this movie was filmed at the beginning of the twenty-first century. We can rejoice and believe that the villains have been defeated, only if we can forget their names and accept the logic of miracles, if we do not remember the king's genealogy, if we leave behind a past of crimes without punishment, if we believe in fairy tales, if we manage to displace inconvenient historical readings. Pan's Labyrinth tells a story apparently distant in time but whose resolution tells a familiar and well-known story that is usually silenced. Seen as a fairy tale, the Spanish "miracle" is not really far from the logic of magic and fantasy that fuels the movie: the lack of memory about the past crimes, the twisted heritage that covers the fascist continuance and the need for secrecy concerning that origin, are dramatically coincident. The movie essays a soothing way to relate an uncomfortable and controversial Spanish history, depicting a national conscience lulled to sleep by a song whose lyrics have been forgotten, suggesting that sleeping and forgetting are the best preparation for building a positive future. 


\section{Bibliografia citada}

Deveny, Thomas. "Once upon a Time in Spain in 1944: The Morphology of El laberinto del Fauno". Journal of Interdisciplinary Studies on Film in Spanish 1, 1 (2008): 112.

Gavela Ramos, Yvonne. "El acto colectivo de recordar: historia y fantasía en El espíritu de la colmena y El laberinto del fauno". Bulletin of Hispanic Studies 88, 2 (2011): 179-19.

Hanley, Jane. "The walls fall down: Fantasy and power in El laberinto del fauno". Studies in Hispanic Cinemas 4, 1 (2007): 35-45.

Juliá, Santos (2006). Memoria de la guerra y del franquismo. Madrid: Taurus.

Loureiro, Ángel (2002). "Pathetic Arguments" Labanyi, Jo (ed.) Constructing Identity in Contemporary Spain. Theoretical Debates and Cultural Practice. New York: Oxford University Press: 225-237.

Medina Domínguez, Alberto (2001). Exorcismos de la memoria: políticas y poéticas de la melancolía en la España de la Transición. Madrid: Libertarias.

Subirats, Eduardo (1995). España: Miradas fin de siglo. Madrid: Akal.

Vilarós, Teresa (1998). El mono del desencanto. Una crítica cultural de la transición española (1973-1993). Madrid: Siglo XXI.

\section{Filmografia}

Del Toro, Guillermo (2006). El laberinto del fauno. España, México y Estados Unidos: Estudios Picasso, Esperanto Films y Tequila Gang. 